\title{
Effect of Various Rootstocks on the Growth and Yield of Valencia Orange, Marsh Seedless Grapefruit, and Ortanique Trees in Jamaica ${ }^{1}$
}

\author{
C. C. Weir ${ }^{2}$
}

\begin{abstract}
The effect of six commercial citrus rootstocks on the growth and yield of Valencia orange, Marsh seedless grapefruit, and Ortanique trees was studied in a rootstock experiment initiated in Jamaica in 1965. Results of these investigations revealed that under the soil and environmental conditions of this experiment, rough lemon and Rangpur lime rootstocks were the most vigorous of the six stocks studied; Cleopatra mandarin was the next most vigorous, while the trifoliate orange was decidedly the least vigorous of the stocks. The widely used sour orange stock was a relatively slow growing stock, and its vigour was about equal to the Troyer citrange rootstock.

Yield data taken over the 3-year period 1969 to 1972 showed that the sour orange rootstock produced yilis of Valencia orange, Marsh seedless grapefruit, and Ortaniques as good as the more vigorous rough lemon and Rangpur lime rootstocks, and better than the other three stocks, viz., Cleopatra mandarin, Troyer citrange, and trifoliate orange.
\end{abstract}

\section{INTRODUCTION}

As stated by Hume (3), in the cultivation of citrus trees no problem requires more thorough consideration from all aspects than that of rootstocks. Their adaptability to the soil and to the inserted scion, their resistance to diseases, and their influence on fruit yield and quality are of utmost importance. Because of its resistance to Phytophthora gummosis (foot-rot) disease, the sour orange has long been the most popular rootstock used in Jamaica. It is estimated that approximately $90 \%$ of all the citrus varieties grown in Jamaica are budded on to this rootstock.

But the sour orange is very susceptible to the dreaded tristeza virus, a disease which resulted in the loss of almost 20 million citrus trees in Brazil, Argentina, Paraguay, and Uruguay during the 1940's. The tristeza virus is not an immediate danger to the Jamaican citrus industry, mainly because the efficient vector, (the black citrus aphid - Toxoptera citricidus Kirk), is not present here. However, tristeza virus should still be considered as a potential threat to the Jamaican citrus

${ }^{1}$ Manuscript submitted to Editorial Board October 31, 1974.

${ }^{2}$ Crops and Soils Division, Ministry of Agriculture, Jamaica. 
industry, and based on the experience of other citrus-producing countries, other tristeza-tolerant rootstocks should be considered in areas suitable for their introduction.

Investigations concerning the use of citrus rootstocks in the Caribbean region were started by the Citrus Research Unit of the University of the West Indies in 1964. A comprehensive series of rootstock trials was initiated in Trinidad, Dominica, Jamaica, and British Honduras. This paper reports the effect of six commercial rootstocks on the yield and growth of Valencia orange, Marsh seedless grapefruit, and Ortanique trees. The effect of these rootstocks on the leaf-nutrient composition of Valencia orange trees was reported in an earlier article (6).

\section{MATERIALS AND METHODS}

The investigation was carried out at Alcan Estates Limited, Williamsfield, Manchester, and the design consisted of five or six treatments (i.e. rootstocks) replicated six times in a randomized block pattern. The plot size was six trees and the planting distance $6.1 \times 6.1 \mathrm{~m}(20 \times 20 \mathrm{ft})$. These experiments were initiated in 1964 . Further details can be obtained from Citrus Research Annual Reports 1963 to 1970 (1) and from Weir et al. (6).

The soil type at the experimental site is a brown clay loam with good structure, known locally as the Chudleigh clay loam (No. 73 in the Jamaican classification). From a soil fertility standpoint, the soil is low in available $\mathrm{K}$ and $\mathrm{N}$ and moderately high in available $\mathrm{P}(5)$. The reaction of this soil type usually varies from slightly acid to neutral.

The experimental trees received fertilizers twice per year, (April and September), and over the past 3 years a 20-0-20 mixture has been used at the rate of $1.8 \mathrm{~kg} /$ tree/year $(4 \mathrm{lb})$.

The rootstocks investigated were: 1) Sour or bitter orange (Citrus aurantium L.); 2) Rangpur lime (Citrus limonia Osbeek); 3) rough lemon (Citrus jamberi Lush.); 4) Cleopatra mandarin (Citrus reshni Tan.); 5) trifoliate orange (Poncirus trifoliata L.); and 6) Troyer citrange (a hybrid of Washington navel crossed with trifoliate orange).

The budwood used for propagating the Valencia orange and Marsh seedless grapefruit was imported from Florida and was certified virusfree nucellar material. For the propagation of the Ortanique trees, the budwood used was collected locally from trees not indexed for any of the main citrus viruses.

\section{RESULTS AND DISCUSSION}

GROWTH

It is not surprising to find that the rough lemon rootstock was, in general, the most vigorous of the six stocks tested (table 1). This was 
particularly true for Ortanique trees, where rough lemon produced trees with significantly larger trunks than all the other rootstocks except Cleopatra mandarin and sour orange; for Valencia orange, the vigour of rough lemon stock was clearly evident up to 1970, producing larger trees than the other stocks, except Rangpur lime. However, by 1972 trees on rough lemon stock were only significantly larger than those on sour orange and Troyer citrange. For the Marsh seedless grapefruit trees,

TABLE 1.-Scion girth measurements in centimeters-1967-1972 (taken $5 \mathrm{~cm}$ above bud union)

\begin{tabular}{|c|c|c|c|c|c|}
\hline Rootstock & 1967 & 1968 & 1969 & 1970 & 1972 \\
\hline & \multicolumn{5}{|c|}{ Ortanique } \\
\hline Rough lemon & 17.8 & 26.2 & 28.7 & 38.0 & 50.1 \\
\hline Cleopatra mandarin & 17.0 & 23.7 & 27.0 & 36.4 & 48.5 \\
\hline Sour orange & 16.7 & 23.7 & 26.4 & 35.1 & 43.0 \\
\hline Rangpur lime & 17.5 & 24.8 & 27.5 & 32.5 & 37.7 \\
\hline Troyer citrange & 17.2 & 20.5 & 23.7 & 28.5 & 33.0 \\
\hline Trifoliate orange & 13.7 & 15.0 & 17.2 & 24.0 & 26.6 \\
\hline L.S.D. $(\mathrm{P}=0.05)$ & 2.7 & 3.2 & 5.0 & 6.0 & 7.2 \\
\hline \multirow[t]{2}{*}{$(\mathrm{P}=0.01)$} & 3.7 & 4.5 & 6.8 & 8.0 & 10.0 \\
\hline & \multicolumn{5}{|c|}{ Marsh seedless } \\
\hline Rough lemon & 13.3 & 26.1 & 31.2 & 37.5 & 52.7 \\
\hline Cleopatra mandarin & 13.0 & 26.4 & 32.2 & 37.8 & 52.5 \\
\hline Sour orange & 10.8 & 24.3 & 28.7 & 34.8 & 45.3 \\
\hline Rangpur lime & 12.5 & $27 . \overline{3}$ & 33.2 & 40.0 & 56.5 \\
\hline Troyer citrange & 12.0 & 22.8 & 31.7 & 35.7 & 47.7 \\
\hline L.S.D. $(P=0.05)$ & 3.3 & 5.0 & 5.2 & 5.7 & 7.5 \\
\hline \multirow[t]{2}{*}{$(\mathrm{P}=0.01)$} & 4.5 & 6.8 & 7.0 & 7.7 & 10.2 \\
\hline & \multicolumn{5}{|c|}{ Valencia orange } \\
\hline Rough lemon & 13.8 & 24.7 & 27.7 & 37.2 & 51.0 \\
\hline Cleopatra mandarin & 8.0 & 17.0 & 23.0 & 31.2 & 44.7 \\
\hline Sour orange & 11.5 & 19.5 & 25.0 & 30.2 & 42.0 \\
\hline Rangpur lime & 10.8 & 19.7 & 24.8 & 32.2 & 45.3 \\
\hline Troyer citrange & 9.2 & 19.6 & 26.1 & 31.2 & 41.7 \\
\hline L.S.D. $(P=0.05)$ & 2.7 & 4.2 & 4.7 & 5.2 & 8.2 \\
\hline$(\mathrm{P}=0.01)$ & 3.7 & 5.7 & 6.5 & 7.0 & 11.2 \\
\hline
\end{tabular}

Rangpur lime was decidedly the most vigorous stock and produced significantly larger trees than Troyer citrange and sour orange stocks.

Table 1 also reveals that the sour orange stock is not very fast growing, and the growth data would suggest that it is not well suited for use on the light infertile bauxite soils of Manchester.

However, Rangpur lime, when certified virus-free orange and grapefruit budwood was used, was equal in performance to rough lemon in terms of vigour; but when the locat non-virus-free Ortanique budwood 
was used, Rangpur lime produced many dwarfed and stunted trees, showing clear symptoms of exocortis virus (or scaly butt) disease.

The same can be said of Troyer citrange and trifoliate orange stocks, which are also quite susceptible to this virus. Because Rangpur lime is tolerant to tristeza virus and to foot rot (gummosis), it could be used as a replacement for sour orange in wet low-lying areas where tristeza might be a problem. However, it is extremely important that the scion material used must be free from exocortis virus whenever Rangpur lime is used.

Cleopatra mandarin deserves special mention since this stock is well adapted to many citrus varieties and also to a wide range of soil conditions. Results in table 1 show that it produced slightly larger scions than the standard sour orange. In addition, Cleopatra mandarin, like sour orange, is fairly resistant to foot rot; but unlike sour orange, it was not susceptible to tristeza.

The rootstock trifoliate orange has merit only in being a dwarfing stock. Like Rangpur lime, trifoliate orange is very resistant to foot rot and tristeza, but it is very susceptible to exocortis. Trifoliate orange could become important in the Jamaican citrus industry only if growers become interested in the system of high density plantings being contemplated in other countries (4).

YIELD

Generally speaking, the pattern of yields for Valencia orange, Marsh seedless grapefruit, and Ortanique (table 2) seems to follow closely the same trend as the growth data in table 1 , with a few exceptions. The most significant deviation was the sour orange stock. This stock is not a vigorous one and produced smaller trees than Rangpur lime and rough lemon stocks. However, in general, the sour orange produced yields of Valencia orange and Ortanique as good as rough lemon and better than Rangpur lime. For grapefruit, only Rangpur lime produced a significantly higher yield than sour orange.

Although Cleopatra mandarin produced larger scions, it did not produce yields comparable to those of sour orange, rough lemon, or Rangpur lime. However, some workers (2) feel that scion varieties budded onto Cleopatra mandarin do not attain their maximum yield potential as quickly as those on sour orange and Rangpur lime. Consequently, scions on Cleopatra mandarin yield less than on other rootstocks of similar age.

The yields of Ortanique from the three exocortis-susceptible stocks, i.e., Rangpur lime, Troyer citrange, and trifoliate orange, reported in table 2, are somewhat misleading since these yields include dwarfed and stunted low-producing trees as well as apparently healthy good-producing trees. Recalculations, based on the yield of healthy trees, revealed 
TABLE 2.-Rootstock experiment yield data summary (kilograms per tree)

\begin{tabular}{|c|c|c|c|c|c|c|c|c|c|}
\hline \multirow[b]{2}{*}{ Rootstock } & \multicolumn{3}{|c|}{$1969 / 70$} & \multicolumn{3}{|c|}{$1970 / 71$} & \multicolumn{3}{|c|}{$1971 / 72$} \\
\hline & Valencia & $\begin{array}{c}\text { Marsh } \\
\text { seedless }\end{array}$ & Ortanique & Valencia & $\begin{array}{c}\text { Marsh } \\
\text { seedless }\end{array}$ & Ortanique & Valencia & $\begin{array}{c}\text { Marsh } \\
\text { seedless }\end{array}$ & Ortanique \\
\hline Rough lemon & 62 & 31 & 44 & 103 & 150 & 136 & 177 & 163 & 173 \\
\hline Rangpur lime & 48 & 47 & 61 & 82 & 150 & 125 & 155 & 225 & 148 \\
\hline Sour orange & 59 & 26 & 50 & 66 & 142 & 114 & 173 & 155 & 176 \\
\hline Cleopatra mandarin & 37 & 19 & 37 & 52 & 131 & 93 & 122 & 136 & 137 \\
\hline Troyer citrange & 56 & 48 & 26 & 62 & 122 & 75 & 155 & 140 & 82 \\
\hline Trifoliate & - & - & 29 & - & - & 50 & - & - & 68 \\
\hline C.V. $\%$ & 43 & 45 & 39 & 22 & 30 & 22 & 33 & 27 & 24 \\
\hline L.S.D. $(P=0.05)$ & 26 & 16 & 20 & 20 & 58 & 23 & N.S. & 65 & 39 \\
\hline
\end{tabular}


that the yield of Ortaniques from Rangpur lime, Troyer citrange, and trifoliate orange stocks were 177,128 , and $123 \mathrm{~kg}$, respectively, compared to the overall values of 148,82 , and $68 \mathrm{~kg}$ for these three rootstocks reported in table 2 .

The performance of those Ortanique tre' (on the above three rootstocks), which have shown no symptoms of exocortis disease so far and at the same time are also high yielders, is being closely watched. Such trees, when properly indext. for the main citrus viruses, could be the source of certified virus-free Ortanique budwood for the propagation of Ortanique trees in Jamaica.

\section{RESUMEN}

El efecto en el crecimiento y rendimiento del chino (naranjo dulce) Valencia, el toronjo Marsh seedless y ortanique de seis portainjertos, se estudió en un experimento iniciado en Jamaica en 1965. Los resultados de esta investigación revelaron que, dentro de las condiciones de suelo y clima en que se realizó, los patrones de limonero rugoso (rough lemon) y de limero Rangpur fueron los más vigorosos, siguiéndoles el mandarino Cleopatra; mientras que el chino (naranjo) trifoliado decididamente fue el más débil. El naranjo agrio, tan extensamente usado como patrón, fue relativamente lento en crecimiento y casi igual al citrange Troyer en cuanto a vigor.

Los datos de rendimiento recolectados en un período de 3 años entre 1969 y 1972 demostraron que con el patrón de naranjo agrio se lograron rendimientos de china (naranja dulce) Valencia, toronja Marsh seedless y ortanique tan buenos como con los más vigorosos de limonero rugoso y limero Rangpur, y a la vez mejores que con mandarino Cleopatra, citrange Troyer y chino (naranjo) trifoliado.

\section{LITERATURE CITED}

1. Citrus Research Annual Reports, Univ. West Indies, Trinidad, 1963-1970.

2. Hosein, I., Citrus rootstocks for the Caribbean area, Bull. No. 15, Citrus Res. Dep., Univ. West Indies, Trinidad, 1969.

3. Hume, H. H., Citrus fruits, (Revised edition), New York, U.S.A., 1959.

4. Phillips, R. L., Dwarfing rootstocks for citrus, Proc. First Int. Citrus Symp. (Vol. I), pp. 401-7, 1968.

5. Weir, C. C., Evaluation of chemical soil tests for phosphate on Jamaican soils, Trop, Agr. (Trinidad) 39: 67-72, 1962.

6. - Hosein, I., and Jones, R. L., Influence of citrus rootstocks on the nutrient composition of Valencia orange leaves, Trop. Agr. (Trinidad), 47: 331-4, 1970. 